| Research Article / Araştırma Makalesi|

\title{
Evaluation of the Academic and Administrative Process in the Institutes of Educational Sciences of Universities
}

\section{Üniversitelerin Eğitim Bilimleri Enstitülerindeki Akademik ve İdari Sürecin Değerlendirilmesi ${ }^{1}$}

\section{Gürcü Erdamar², Serap Nur Duman ${ }^{3}$}

\author{
Keywords \\ 1. educational sciences \\ 2. institute \\ 3. postgraduate \\ education \\ 4. academic and \\ administrative process.

\section{Anahtar Kelimeler} \\ 1. eğitim bilimleri \\ 2. enstitü \\ 3. lisansüstü eğitim \\ 4. akademik ve idari \\ süreç
}

Received/Başvuru Tarihi

22.03.2021

Accepted / Kabul Tarihi 07.06.2021

\begin{abstract}
This study aims to understand the course of the academic and administrative processes in the institutes of educational sciences and reveal the problems encountered in these processes. Based on this objective, 23 institutes of educational sciences located in Turkey were reached. The entire population was included in the study conducted in survey research design. The study group consisted of a total of 98 administrators including 24 institute administrators (director and deputy directors) and 74 heads of division / heads of department in 23 institutes of educational sciences. The research data were collected by a questionnaire prepared by the researchers. The questionnaire contained a total of 64 items under the titles of administration, advisory services, official correspondence and announcements, personnel, physical facilities, student, cooperation, and the attractiveness of the institute. The analysis program SPSS was used in the analysis of data that were collected in approximately two months. Based on the findings obtained, the use of electronic information and information technology systems in institute correspondence, the accessibility of the institute director and deputy directors by faculty members, the actualization of advisor assignments in accordance with the regulations, the need for more support to the institute budget, and the representation of institute directors in the university administrative committee are the items with which the administrators agree most. However, the items with which the administrators agree least are the availability of separate classrooms for postgraduate programs and of appropriate physical conditions for academic activities in institutes, students' knowledge of postgraduate regulations, cooperation with the institutes of educational sciences of other universities, the decrease in the interest in the institute programs, and gathering institutes under one roof.
\end{abstract}

Öz

Bu araştırmada, eğitim bilimleri enstitülerinin akademik ve idari süreçlerinin işleyişini anlamak ve bu süreçlerde yaşanan sorunları ortaya koymak amaçlanmıştır. Bu amaca dayalı olarak Türkiye'de bulunan 23 eğitim bilimleri enstitüsüne ulaşılmıştır. Tarama modelinde gerçekleştirilen araştırmanın evrenin tamamı araştırmaya dahil edilmiştir. 23 eğitim bilimleri enstitüsünde bulunan 24 enstitü yöneticisi (müdür ve müdür yardımcısı) ile 74 bölüm / anabilim dalı başkanı olmak üzere toplam 98 yönetici araştırmanın çalışma grubunu oluşturmuştur. Araştırmanın verileri, araştırmacılar tarafından hazırlanan anket ile toplanmıştır. Anket formunda yönetim, danışmanlık hizmetleri, resmi yazışma ve duyurular, personel, fiziki olanaklar, öğrenci, iş birliği ve enstitünün çekiciliği başlıklarında toplam 64 madde yer almaktadır. Yaklaşık iki ay içinde toplanan verilerin analizinde SPSS analiz programından yararlanılmıştır. Elde edilen bulgulara dayalı olarak yöneticilerin en çok katıldığı maddeler; enstitü yazışmalarında elektronik bilgi ve bilişim sistemlerinden yararlanılması, enstitü müdürü ve yardımcılarının öğretim üyeleri için ulaşılabilir olması, danışman atamalarının yönetmeliklere uygun gerçekleştirilmesi, enstitülerin daha fazla bütçe desteğine intiyaç duyduğu ve enstitü müdürlerinin üniversite yönetim kurulunda temsil edilmesi ile ilgilidir. Yöneticilerin en az katıldığı maddeler ise, enstitülerin lisansüstü dersler için ayrı dersliklerinin ve akademik etkinlikler için uygun fiziki koşulların bulunması, öğrencilerin lisansüstü yönetmelikler hakkında bilgi sahibi olması, diğer üniversitelerin eğitim bilimleri enstitüleri ile işbirliği yapılması, enstitü programlarına olan ilginin azalması ve enstitülerin tek bir çatı altında toplanmasıdır.

\footnotetext{
${ }^{1}$ This article is was presented as a summary paper at the IPCEDU Congress-2020.

${ }^{2}$ Gazi University, Faculty of Education, Department of Educational Sciences, Ankara, TURKEY; https://orcid.org/ 0000-0001-6753-0151

${ }^{3}$ Corresponded Author, Kırıkkale University, Faculty of Education, Department of Educational Sciences, Kırıkkale, TURKEY; https://orcid.org/ 0000-0002-45352144
}

Citation/Alıntı: Erdamar, G., \& Duman, i. N. (2021). Evaluation of the academic and administrative process in the ınstitutes of educational sciences of universities. Kastamonu Education Journal, 29(4), 261-272. doi: 10.24106/kefdergi.901167 


\section{INTRODUCTION}

It can be said that one of the most important factors determining the competitiveness of countries is the qualified manpower they train. Qualified manpower refers to individuals who can think critically, solve problems, adapt, be flexible and creative, produce and spread knowledge, make use of technology, and work in a collaborative manner (Borich, 2004; Cruickshank, Jenkins \& Metcalf, 2003; Dilci \& Gürol, 2012; Moore, 2005). In fact, the training of qualified scholars and lecturers at higher education level is carried out through the postgraduate education institutes and curricula of higher education institutions. Through postgraduate education, in addition to produce knowledge, theoretical and applied studies are carried out and a connection is established between these two fields (Alabaş, Kamer \& Polat, 2012). In other words, postgraduate education aims to train scholars who study more deeply in a scientific field, have gained academic skills and professional competence, and are able to conduct original and independent scientific research (Aitken, Currey, Marshall \& Elliott, 2008; Ekinci, 2011; Rust, 2009). In this way, postgraduate education contributes significantly to the countries in terms of their scientific, technological, social, economic, and political growth, and therefore, enables development and allows countries to find solutions to the problems with which they face. Effective planning and implementation of postgraduate education is closely related to the level of development of the country.

The most important tasks of higher education institutions are to bring science and technology together, to support research culture, technological advance, and entrepreneurship, to make contribution to develop policies for the problems in society, and to mentor for public and private enterprises (Etzkowitz, 2003; ibiş, 2014; Özer, 2011; Öztemel, 2013; Şen, 2012; Yıldız, 2019). For these reasons, it means that countries allocate resources for education and scientific studies and invest in future (Karakütük, 2001). Postgraduate education started in Germany almost two hundred years ago and today it is among the main objectives of higher education institutions (Türker, 1997). Postgraduate education in Turkey maintained as doctorate following undergraduate degree until the 1960s and after the 1970s, it was actualized as masters and doctorate education (Aricl, 2001). Although there are different definitions regarding postgraduate education in the literature, the scope of postgraduate education is based on education and training, professional development, professional and academic culture, scientific research and scientific perspective, scientific attitude and behavior, interdisciplinary study, teaching to learn, and ethics (Erdem, 2007; Ince \& Korkusuz, 2006; Sevinç, 2001).

It is also seen that the importance of and the trend towards postgraduate education in Turkey have increased recently (Bülbül, 2003) and the number of institutes increases as new universities are opened (Şaşmaz-Ören \& Karapınar, 2016). In our country, postgraduate education is provided in 526 institutes of 54 different types and within the scope of 18.468 postgraduate programs. Institutes with the highest number of students are, respectively, Social Sciences, Science, Health Sciences, Educational Sciences, and Fine Arts institutes (Günay, 2018). According to the CoHE (2021) statistics, the total number of graduate students is 297.001 and the total number of doctoral students is 101.242. Based on the CoHE 2021 data, approximately $7 \%$ of students with bachelor's degree receive postgraduate education. Nearly half of teachers $(49,3 \%)$ has bachelor's degree in the average for OECD countries and this ratio is $92,3 \%$ in Turkey. Among the countries participating in the TALIS 2018 Survey, Turkey is the second country where the ratio of graduated teachers is the most. However, $44,2 \%$ of teachers in the OECD countries has master's degree, while the ratio is only $6,3 \%$ for teachers in Turkey. Regarding doctoral degree, these rates are $1,3 \%$ in the OECD countries and $0,2 \%$ in Turkey (TEDMEM, 2019). It is seen that the emphasis on postgraduate education has gradually increased in Turkey. Determining the priority areas in postgraduate education and offering scholarships for doctoral students, sending PhD students to study abroad, and employing PhD researchers can be regarded as the indications of importance given (Ertem, 2020).

However, in comparison to the OECD average, it can be stated that the desired rate has not been reached, yet. As it is seen, one of the important institutes in universities is the Institute of Educational Sciences. Although universities have recently gathered different institutes under the name of Institute of Postgraduate Education, the Institute of Educational Sciences (IES) is present in 23 universities in Turkey for the year 2020. The main objectives of IES are to conduct effective studies at national and international level in the field of education and research, to develop new approaches to resolve the issues in educational sciences, and to train qualified scholars. As in other fields, in the field of educational sciences, information is constantly updated, existing practices are questioned, and recent learning-teaching conceptions and beliefs are discussed. For this reason, prospective teachers who have newly graduated from pre-service training programs and teachers who are in-service must always adapt themselves and maintain their professional development (Barnes \& Shirley, 2007; Hulse \& Hulme, 2012). Teachers receiving postgraduate education will be able to instruct more effectively in their classes by improving themselves both academically and professionally (Başer, Narlı \& Günhan, 2010). Promoting their students' scientific thinking, critical thinking, problem solving and decision-making skills and encouraging them to learn how to learn are of the most important duties of teachers (Köksalan, ilter \& Görmez, 2010; Nachiappan, Shukor, Veeran \& Andi, 2012; Sasaki \& Mällinen, 2018; Şaşmaz-Ören \& Karapınar, 2016). In most of the countries that succeeded in the PISA and TIMMS tests (Finland, Singapore, Japan, New Zealand, and etc.), teachers are encouraged to receive postgraduate education, and even, it is implemented as a requirement for teaching in Finland (Mete, 2013). According to the CoHE (2021) data, there are 25.850 graduate and 6.577 doctoral students in IESs for the academic year 2019-2020. Considering teachers in service and prospective teachers newly graduated from faculty of education, this number should be increased, based on the fact that teachers specialize in their fields and render the teaching process more qualified by improving their competencies in the field of scientific research thanks to postgraduate education.

Studies on postgraduate education are encountered in the literature review. However, some of them focus on the problems experienced by the students at the institutes of educational sciences (Aktan, 2020; Alabaş, Kamer \& Polat, 2012; Başer, Narlı \& 
Günhan, 2005; Karakütük, Aydın, Abalı \& Yıldırım, 2008; Kurnaz \& Alev, 2009; Karaman \& Bakırcı, 2010; Topal, Sağlam \& Akgün, 2017), while some investigate prospective teachers' opinions, attitudes and expectations towards postgraduate education (Alabaş, Kamer \& Polat, 2012; Alhas, 2006; Arı, Pehlivanlar \& Çömek, 2005; Aydemir \& Çam, 2015; Baş, 2013; Başer, Narlı \& Günhan, 2010; Dilci \& Gürol, 2012; Er \& Ünal, 2017; Gömleksiz \& Yıldırım, 2013; Hulse \& Hulme, 2012; illhan, Öner Sünkür \& Yılmaz, 2012; İnelEkici, Ekici \& Can, 2020; Kaya, 2014; Köksalan, Illter \& Görmez, 2010; Oluk \& Çolak, 2005; Ören, Yılmaz \& Güçlü, 2012; Şahin, Demir \& Arcagök, 2015; Ünal \& IIlter, 2010; Tonbul, 2017; Yıldız \& Göl, 2016). There are also some studies that analyze academicians' opinions on postgraduate education (Bülbül, 2003; Büyüköztürk \& Köklü, 1999; Dilci \& Gürol, 2012; Tonbul, 2017).

In postgraduate programs, students are expected to specialize in their fields, acquire scientific research competencies, reach new syntheses by interpreting scientific evidence, and carry out authentic scientific research. In addition to these tasks, IESs should support teachers to improve themselves in their professional lives and to apply the developments in educational sciences to their teaching processes. Institutes should be managed well in terms of academic and administrative processes so that the instructional programs training scholars can attain their objectives. In this study, it is aimed to analyze how the academic and administrative processes of the institutes of educational sciences work and what the problems encountered in the process are, which have not much been handled as research subject in the literature, from the perspective of institute administrators and heads of division and department.

\section{METHOD}

\section{Research Model}

This study adopts survey research design since the opinions of institute administrators and heads of division/department of the relevant programs regarding academic and administrative processes of Institutes of Educational Sciences are explained as they are. Survey research includes studies that aim to collect data through questionnaire or interview in order to understand the opinions, attitudes or characteristics of participants (Creswell, 2017, p. 481).

\section{Study Group}

While forming the study group of the research, universities where IES is present were determined first. In Turkey, there are 23 universities in which the institute of educational sciences is available. All of the directors and deputy directors working in these institutes and all of the heads of division/department that has postgraduate education programs in the institutes were included in the research. For this reason, instead of selecting a sample, the entire population was included in the study group. Of the institute administrators and heads of division/department who work in 23 universities, 98 participated in the study. Detailed information about the study group is presented in Table 1 and Table 2.

Table 1. Universities where IES is present

\begin{tabular}{l} 
University \\
1. Akdeniz University \\
2. Bartın University \\
3. Burdur Mehmet Akif Ersoy University \\
4. Bursa Uludağ University \\
5.Çanakkale On Sekiz Mart University \\
6. Dicle University \\
7. Ege University \\
8. Erciyes University \\
9. Fırat University \\
10. Gazi University \\
11. Gaziantep University \\
12. Inönü University \\
13. Mersin University \\
14. Muğla Sıtkı Koçman University \\
15. Necmettin Erbakan University \\
16. Niğde Ömer Halisdemir University \\
17. On Dokuz Mayıs University \\
\hline
\end{tabular}



University
18. Sakarya University
19. Selçuk University
20. Sivas Cumhuriyet University
21. Süleyman Demirel University
22. Tokat Gaziosmanpaşa University
23. Van Yüzüncü Yıl University

There are IESs in 23 universities in Turkey. Table 1 shows that there is no IES in any of the private universities and all these institutes are located in the state universities. While more universities had IESs in previous years, the institutes of some universities (institutes of science, health, social sciences, education, and etc.) have been gathered under a single name as the Institute of Postgraduate Education in recent years. Table 2 presents information about the institute directors and deputy directors working in the 23 IESs and voluntarily participating in the study and also information about the heads of division/department which has programs in these institutes.

Table 2. Information about the institute administrators participating in the study $(n=98)$

\begin{tabular}{lcc}
\hline Variables & N & $\%$ \\
\hline Participants & & \\
\hline $\begin{array}{l}\text { Institute Administrators } \\
\text { (director and deputy directors) }\end{array}$ & 24 & 24.4 \\
Heads of Division / Departments & 74 & 75.5 \\
Academic Title & & \\
\hline Professor & 54 & 55.1 \\
Associate Professor & 28 & 28.5 \\
Doctor Lecturer & 16 & 16.3 \\
Professional Seniority & & \\
\hline $1-5$ years & 5 & 5.1 \\
6-10 years & 5 & 5.1 \\
$11-15$ years & 2 & 2 \\
16-20 years & 12 & 12.2 \\
21 years and above & 74 & 75.5 \\
\hline
\end{tabular}

24 institute administrators ( 12 directors and 12 deputy directors) and 74 heads of division / department (11 heads of division and 63 heads of department) were included in the study group. 54 of the participants are professor, 28 of them are associate professor and 16 of them are doctor lecturer. 9 of the institute administrators, 7 of the heads of division, and 38 of the heads of department are professors. 7 of the institute administrators, 2 of the heads of division, and 19 of the heads of department are associate professors. The other participants are doctor lecturers. Concerning the distribution of the participants according to their professional seniority, it is seen that they generally work for 21 years and above (75.5\%). It is also seen that the institute administrators serve for 1 to 8 years, heads of division for 1 to 3 years, and heads of department for 1 to 13 years.

\section{Data Collection Tools}

The questionnaire developed by the researchers was used as data collection tools in the study. In order to develop the questionnaire, the literature review regarding the studies investigating postgraduate education, IES, and academic and administrative problems in the institutes was initially carried out, and the results of national and international studies that were relevant to the research subject were examined. Then, the question pool including the list of questions that may be selected for data collection tool was created. The prepared questionnaire form consisted of 82 items. The questionnaire form was sent to seven experts in the field, as one director of institute, three deputy directors of institute, and three heads of division/department, who work or have previously worked in the IES. As a result of expert opinions, which obtained in approximately three weeks, the questions were reviewed. Some questions were excluded, some new questions were added, and necessary corrections were made on some of the questions. In the final draft of the questionnaire, a total of 64 items were included under the titles of administration, advisory services, official correspondence and announcements, personnel, physical facilities, student, cooperation, and the attractiveness of the institute.

The questionnaire form used in the study was arranged in two parts. The first part of the questionnaire differs as intended for the heads of division/department and institute administrators. In the first part of the questionnaire for institute administrators, title, administrative duty, tenure, and the number of academic / administrative personnel serving in the institute were asked. In the first part of the questionnaire for the heads of department, information about title, tenure, and postgraduate programs of the 
department was collected. The values of Cronbach's Alpha reliability for the questionnaire parts are presented in Table 3. Accordingly, the values of reliability for the questionnaire parts vary between .74 and .89 .

Table 3. Parts in the questionnaire and values of reliability

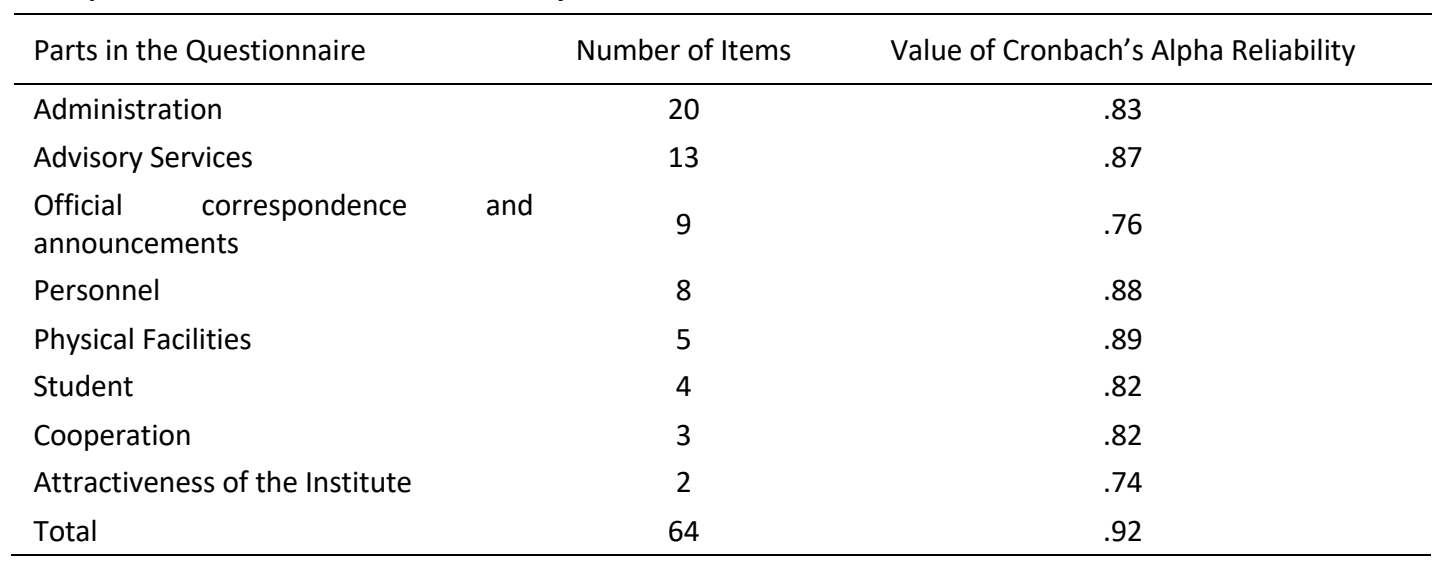

\section{Data Collection}

The questionnaire form was sent to the IES administrators and heads of department participating in the study by e-mail. It was forwarded to the personal e-mail addresses on the web pages of the universities or IESs of which the participants are a member. 98 of the institute administrators and heads of division/department who worked in the 23 IESs accepted to participate in the study and filled out the questionnaire. No e-mails were received from the other participants. The data collection process was completed in two months on the average (August 2020 - September 2020).

\section{Data Analysis}

Data were analyzed by the statistical analysis program SPSS. The data related to the first part of the data collection tool were used to describe the study group in the research after frequency values were calculated. The mean and standard deviation values for the items in the second part of the questionnaire were presented (Büyüköztürk, 2011, p. 40).

\section{FINDINGS}

The academic and administrative processes in the Institutes of Educational Sciences were examined in terms of administration, official correspondence and announcements, personnel, advisory services, physical facilities, cooperation, student, and attractiveness of the institute. The relevant data were presented in Table 4.

Table 4. Administrator opinions regarding the academic and administrative process in the institutes of educational sciences

\begin{tabular}{|c|c|c|}
\hline & $\overline{\mathrm{X}}$ & SS \\
\hline \multicolumn{3}{|l|}{ Administration } \\
\hline Institute administrative board members have a grasp of the regulations. & 3,59 & 1,04 \\
\hline Institute administrative board members attend the meetings regularly. & 3,92 & 1,02 \\
\hline $\begin{array}{l}\text { Decisions of the administrative board of the institute are noted down promptly by the relevant officer and } \\
\text { carried into effect. }\end{array}$ & 3,97 & 1,04 \\
\hline $\begin{array}{l}\text { Council members of institute present their opinion and suggestion in order to enhance the quality of } \\
\text { postgraduate education. }\end{array}$ & 3,48 & 1,22 \\
\hline Council members of institute attend the meetings regularly. & 3,85 & ,99 \\
\hline Institute administration tries to resolve the issues conveyed in an objective and timely manner. & 3,88 & 1,14 \\
\hline $\begin{array}{l}\text { There is an effective communication and cooperation between the institute administration and } \\
\text { administrative staff. }\end{array}$ & 3,74 & 1,09 \\
\hline Institute administration carries out its works in a transparent and accountable administrative mentality. & 3,76 & 1,20 \\
\hline Institute administration carries out its works in a participatory and democratic administrative mentality. & 3,68 & 1,21 \\
\hline Institute administration carries out its works in a sustainable and uninterrupted service mentality. & 3,86 & 1,03 \\
\hline $\begin{array}{l}\text { Administrative board of the institute was established in a way that can represent the disciplines } \\
\text { (departments / fields of study). }\end{array}$ & 3,65 & 1,15 \\
\hline Frequent amendments to the regulation make the works of the institute administration difficult. & 3,60 & 1,29 \\
\hline $\begin{array}{l}\text { Due to the intensive workload in the institutes, authority and responsibilities regarding some routine works } \\
\text { and transactions can be transferred to the departments and fields of study. }\end{array}$ & 3,65 & 1,15 \\
\hline
\end{tabular}




\begin{tabular}{|c|c|c|}
\hline & $\overline{\mathrm{X}}$ & SS \\
\hline The institute should have an autonomous teaching staff that is independent from the faculty members. & 3,12 & 1,54 \\
\hline The support by the university to the institutes is less than it is to the faculty. & 3,54 & 1,13 \\
\hline Directors of the institutes must be represented in the administrative board of the university & 4,31 & 0,87 \\
\hline All institutes should be gathered under a name like the Institute of Postgraduate Education. & 2,78 & 1,62 \\
\hline More budget support should be given to the institutes. & 4,41 & 0,72 \\
\hline Institute administration carries out its works independently without remaining under any pressure. & 3,45 & 1,25 \\
\hline $\begin{array}{l}\text { Considering the existing structure and equipments, services provided by the institutes can be ensured through } \\
\text { Postgraduate Education Coordinatorships to be established in the relevant faculties of education. }\end{array}$ & 3,42 & 1,30 \\
\hline
\end{tabular}

\section{Advisory Services}

Lecturers follow the advisor approval dates and inform their students.

$3,690,90$

Lecturers have information about the number of courses that students need to take, the ECTS credits, and so on.

Lecturers effectively provide the necessary advisory support regarding the courses to students.

$3,50 \quad 1,04$

Lecturers have information about thesis submission process.

$3,53 \quad 0,99$

Lecturers follow the webpage of the Institute.

$3,04 \quad 0,84$

Students follow the webpage of the Institute.

$3,45 \quad 0,86$

Lecturers have information about the regulations regarding postgraduate education.

$3,17 \quad 0,93$

Postgraduate thesis monitoring committees are regularly held and followed.

$3,92 \quad 0,87$

Evaluation of postgraduate courses is carried out in a timely manner.

$4,11 \quad 0,79$

In MS programs, the number of courses taken is sufficient to graduate from the program.

$3,85 \quad 1,14$

In PhD programs, the number of courses taken is sufficient to graduate from the program.

$3,58 \quad 1,14$

Advisor assignments are carried out in accordance with the institute regulations.

$4,35 \quad 0,79$

Students and lecturers are satisfied with advisor selection.

$3,63 \quad 0,92$

Official Correspondence and Announcements

The heads of department/disciplines regularly follow the letters from the Institute.

4,01,95

The heads of department/disciplines convey the requested information to the Institute in a timely manner.

$3,97 \quad 1,05$

The heads of department/disciplines inform the lecturers about the issues relevant to the Institute in time and accurately.

Necessary announcements and notifications are made on the Institute webpage on time.

News on the meetings to be held is conveyed to the lecturers in time by the Institute.

$4,04,92$

Electronic information and information technology systems are used in the institute correspondence.

$4,09,93$

Information systems of the institute operate as integrated with the e-state automation system.

$4,50,83$

Announcements about the Institute are regularly made to students via social media channels.

$3,56 \quad 1,33$

Announcements about the Institute are sent to students via SMS.

$3,321,09$

\section{Personnel}

The number of administrative staff in the institute is sufficient.

$3,14 \quad 1,22$

The duties and responsibilities of the institute's staff are defined.

$3,08 \quad 1,27$

The institute's staff has a grasp of the regulations, operation and process regarding to postgraduate education.

Director of the Institute is accessible to the lecturers.

Deputy directors of the Institute is accessible to the lecturers

$4,21 \quad 1,14$

Institute student affairs officers are respectful and friendly towards lecturers.

$4,390,99$

Institute student affairs officers are respectful and friendly towards students.

$4,27 \quad 0,95$

Administrative staff is reluctant to work at the institute due to the intensive workload and excessive correspondence.

$3,79 \quad 1,21$

$3,29 \quad 1,18$

\begin{tabular}{|c|c|c|}
\hline \multicolumn{3}{|l|}{ Physical Facilities } \\
\hline \multicolumn{3}{|l|}{ The institute has separate classrooms for postgraduate courses. } \\
\hline The institute has halls reserved for thesis defense. & 3,22 & 1,53 \\
\hline $\begin{array}{l}\text { The institute has halls large enough to be used for the institute administrative board and the council of the } \\
\text { institute. }\end{array}$ & 3,27 & 1,45 \\
\hline Suitable working conditions are available for the administrative staff. & 3,57 & 1,10 \\
\hline $\begin{array}{l}\text { Working environment, staff and equipments required to conduct a series of academic activities (holding a } \\
\text { seminar, conference, and preparing a journal, etc.) are available in the institute. }\end{array}$ & 2,88 & 1,32 \\
\hline
\end{tabular}




\begin{tabular}{|c|c|c|}
\hline Student & & \\
\hline Students have information about the regulations regarding postgraduate education. & 2,76 & 0,98 \\
\hline Students know about the conditions required to complete the postgraduate program. & 3,25 & 0,99 \\
\hline Students are in effective communication with their advisors. & 3,60 & 0,74 \\
\hline Students perform the works expected of them in a timely and qualified manner. & 3,20 & 0,82 \\
\hline \multicolumn{3}{|l|}{ Cooperation } \\
\hline There is an effective cooperation between the disciplines and the Institute. & 3,34 & 1,15 \\
\hline There is an effective cooperation between the faculties and the Institute. & 3,29 & 1,16 \\
\hline Cooperation is made with the Institutes of Educational Sciences of other universities. & 2,93 & 1,07 \\
\hline \multicolumn{3}{|l|}{ Attractiveness of the Institute } \\
\hline Interest in the IES postgraduate programs is decreasing day by day. & 2,18 & 1,13 \\
\hline There is a remarkable decrease in the quality of students applying to IES postgraduate programs. & 3,00 & 1,24 \\
\hline
\end{tabular}

Based on Table 4, the items with the highest average under the title of administration are the necessity for more budget support to be given to the institutes $(X=4.41)$, the necessity for the institute director to be represented in the administrative board of the university $(X=4.31)$, institute administrative board decisions to be noted down promptly by the relevant officer and carried into effect $(\bar{X}=3,97)$, and the regular attendance to the meetings by the institute administrative board members $(X=3,92)$. According to this, institutes have some problems with the budget and representation in the university boards. Although the average of the items related to the IES council members is low, it is understood that council decisions are made and implemented in time. The item with the lowest average under the title of administration is about the gathering all institutes under a single name like the Institute of Postgraduate Education as a single institute $(X=2.78)$. Accordingly, neither the head of the institute nor the heads of the division/department agree about the idea of gathering other institutes under a single institute within the universities. Other items that the administrators agree less are "Council members of institute present their opinion and suggestion in order to enhance the quality of postgraduate education" $(\bar{X}=3,48)$ and "Institute administrative board members have a grasp of the regulations" $(\bar{X}=3,59)$. Based on this, the biggest problem regarding the administration in the IESs is that the council members of institute are inadequate to express their opinions and suggestions on education. Members are expected to state their opinions more in order to improve the quality of education in the institutes of educational sciences. It is also revealed that institute administrative board members do not have full knowledge of the postgraduate regulations. In advisory services, the items with the highest average are "Advisor assignments are carried out in accordance with the institute regulations" ( $\bar{X}=4,35)$ and "Evaluation of postgraduate courses is carried out in a timely manner" ( $\bar{X}=4,11)$. Based on this, it can be said that the selection and appointment of advisors in the institute of educational sciences are carried out in accordance with the postgraduate regulations.

According to the participants, evaluation process is also conducted successfully in the IESs. "Lecturers follow the webpage of the Institute" $(\bar{X}=3,04)$ is the item with the lowest average under the title of advisory services. In addition, that lecturers have information about postgraduate regulations $(X=3.17)$ and students follow the institute webpage $(X=3.45)$ are the items on which the administrators slightly agree. It is especially important that the lecturers participating in the postgraduate education processes follow the news and announcements regarding the institutes. Therefore, it is necessary for the lecturers to follow the web pages of institutes and also guide their students in this regard. Considering the averages of the items under official correspondence and announcements, "Electronic information and information technology systems are used in the institute correspondence" $(\bar{X}=4,50)$ is found as the item with the highest average. The institute administrators and heads of division/department think that news on the meetings to be held is conveyed to the lecturers in time by the institute, necessary announcements and notifications are shared on the institute webpage, and lecturers are informed about the issues relevant to the Institute by the heads of disciplines/departments in time and accurately.

Accordingly, it is understood that the IESs maintain their internal and external communication through the electronic system and this process is an application positively evaluated by the participants. The items with the lowest average under this title are "Announcements about the Institute are sent to students via SMS" $(\bar{X}=3,14)$ and "Announcements about the Institute are regularly made to students via social media channels" ( $\bar{X}=3,32)$. Based on this, it is observed that the announcements by the institute are delivered to the lecturers on time, but there are some problems with reaching the students. Regarding the personnel, "Deputy Directors of the Institute is accessible to the lecturers" ( $\bar{X}=4,39)$, "Institute student affairs officers are respectful and friendly towards lecturers $(\bar{X}=4,27)$, and "Director of the Institute is accessible to the lecturers $(X=4.21)$ are determined as the items on which the administrators agree at most. Based on this, it can be said that the institute administrators (director and deputy directors) and administrative staff are in effective communication with the lecturers. On the other hand, that the number of administrative staff in the institute is sufficient $(\bar{X}=3,08)$ and that administrative staff is reluctant to work at the institute due to the intensive workload and excessive correspondence $(\bar{X}=3,29)$ are found as the items with low averages. In other words, although there are some problems related to the number of administrative staff in the institutes, it can be said that the staff works willingly despite the workload. The item on which the institute administrators and heads of division/department agree at most under the 
title of physical facilities is the availability of suitable working conditions for the administrative staff $(X=3.57)$. Similarly, it can be said that there are no suitable halls in the IESs for the administrative board and the council of the institute and thesis defense.

In terms of physical facilities, the items with the lowest average are "The institute has separate classrooms for postgraduate courses" ( $\overline{\mathrm{X}}=2,49)$ and "Working environment, staff and equipments required to conduct a series of academic activities (holding a seminar, conference, and preparing a journal, etc.) are available in the institute" $(\bar{X}=2,88)$. The biggest problem related to the physical facilities of the institutes which provides postgraduate education is seen to be the classrooms. It is understood that there are not any or only inadequate number of classrooms where lectures and seminar studies can be organized and individual or group studies can be carried out by the students. The item with the highest average under this title is the availability of suitable working conditions for the administrative staff. In other words, although there are offices for the administrative staff in the institutes, there are no classrooms suitable for postgraduate courses and physical conditions for academic activities are not adequate. When the averages of the four items under the student title are considered, the item with the highest average is determined to be "Students are in effective communication with their advisors" $(\bar{X}=3,60)$ and the item with the lowest average is found to be "Students have information about the postgraduate regulations" $(\overline{\mathrm{X}}=2,76)$. It is important for the postgraduate students to know about the regulations in order to complete the postgraduate education process in accordance with the regulations.

Students are expected to have knowledge of the regulations in order to obtain accurate information about the number of courses required to be taken in MS or PhD programs, the ECTS credits necessary to be attained, the selection of the advisor, and thesis period. Besides, the agreement on the view that students can communicate effectively with their advisors is not very high. However, a harmonious relationship between postgraduate students and advisors in the process is highly important. When the averages of the three items under the cooperation title are compared, the averages of the items "There is an effective cooperation between the disciplines and the institute" $(\bar{X}=3,34)$ and "There is an effective cooperation between the faculties and the institute" $(\bar{X}=3,29)$ are found to be high, and the average of the item "Cooperation is made with the Institutes of Educational Sciences of other universities" $(\bar{X}=2,93)$ is found to be low. Based on this, it can be said that the institutes of educational sciences do not have a problem related to the cooperation within the university to which they are institutionally affiliated, but they face with problems in terms of inter-institute cooperation. Lastly, the attractiveness of institute programs in the recent times is evaluated. Accordingly, it is seen that the administrators do not agree on the items that student interest in the IES postgraduate programs is decreasing day by day $(\bar{X}=2,18)$ and there is a decrease in student quality $(\bar{X}=3,00)$. It is pleasing to observe that the number and interest of students receiving postgraduate education is increasing every passing year and what instructors basically expect from postgraduate education is to improve themselves.

\section{DISCUSSION AND CONCLUSION}

The results reached in this study which aims to reveal the course of the academic and administrative processes in the Institutes of Educational Sciences and to find out the problems encountered in these processes are discussed in this part. Considering the administration of the institutes, the smoothest practices are that the institute administrative board decisions are timely registered by the staff and implemented and institute administrative board members attend the meetings regularly. Despite the inadequate number of administrative staff and the intensity in student affairs in the institute, it is very pleasing that the decisions are recorded and put into effect quickly. In their study which institute administrators were included, Karakütük et al. (2008) found that this item was realized best in the institutes. The most significant problems experienced in the administration of the institutes of educational sciences are the insufficient budgets allocated to the institutes and the inability of institute directors to take their parts in the administrative boards of universities. Universities allocate budget at a certain amount to faculties each year, but, unlike faculties, institutes do not have their own budgets.

In Turkey, undergraduate level is administered under the academic title of the Dean and postgraduate level by the Director. Directors of institutes are appointed upon the proposal of the Dean of the relevant faculty, and while deans can participate in the administrative boards of universities, institute directors cannot participate in this board (COHE, 1981). The fact that the institutes of postgraduate education are still administrated in accordance with the law adopted in 1981 constitutes one of the biggest problems. As Gök (2015) also stated, one of the most important issues of institutes is that the representation authority is held by the deanship in faculties and by the directorate in institutes. Whereas directors take part in the university senate, they are not able to attend the meetings of the administrative board of universities. This situation negatively affects both the perspective towards institutes and personal rights of institute administrators. Graduate institutions that do not have their own budgets, classrooms and teaching staff (Bayar \& Duran, 2019; Gök, 2015; Karaman \& Bakırcl, 2010) are perceived at a lower level than faculties that offer undergraduate education although they provide a higher level education. It is required for the institutes to reach their well-deserved position with the necessary changes to be made in the regulations for academic organization.

Other important problems experienced in terms of administration are that administrative board members do not have a comprehensive knowledge of postgraduate regulations and their opinions and suggestions to enhance the quality of education are not sufficient. In order that the IESs can be managed effectively and can fulfill their duties, it is highly important to know and implement the postgraduate regulations on education and training activities in detail by the board members. The administrators who know the regulations very well, make appropriate decisions, and bring forward proposals to increase the quality of postgraduate education in line with their own opinion and suggestions are needed so that the objectives of postgraduate education can be attained. For these reasons, it is necessary to evaluate especially the selection of institute administrative board 
members more meticulously. Regarding the advisory services of lecturers, the institute administrators and heads of division/department mostly agree on the opinion that advisor assignments are carried out in accordance with the regulations and the evaluation of postgraduate courses is carried out in time. Thesis advisors of postgraduate students are assigned by the administrative board of the institute by taking the student request and workload of lecturers into consideration. It is found quite positive that the advisor assignment process is actualized in accordance with the regulations in the 23 institutes of educational sciences in Turkey.

Especially for PhD students, the selection of thesis advisor and determination of thesis subject are very important. If institutes intend to perform an effective administration process, they should pay special attention to the procedures related to advisory. Therefore, institutes should organize seminars for academic advisory trainings and activities for introducing the regulations, offer solutions by detecting the problems of lecturers and students, and ensure the effective course of advisory processes.In terms of advisory services, the item on which the institute administrators agree least is that lecturers follow the institute webpage and announcements. Under the title of the official correspondence and announcements, it is interesting that lecturers do not follow the institute webpage, while corresponding through electronic information systems is found positive. The fact that there are lecturers who do not have a look at the institute webpage, do not read the regulations but still provide advisory brings many problems with it in postgraduate education. The most important problems about advisory services identified in some studies in the national literature are that thesis advisors are unaware of the thesis subject (Varol \& Şeker, 2008), advisors do not spare enough time for students (Çoruk, Çağatay \& Öztürk, 2016; İbiş, 2014; Karaman \& Bakırcı, 2010), thesis studies lack originality and are like the repetition of each other (Adams et al., as cited in Orer, 2011), guidance and advisory services are found insufficient by postgraduate students (Aydın \& Hayal, 2014; Gömleksiz \& Yıldırım, 2013), and postgraduate students experience problems in communicating with their advisors (Arabacı \& Akıllı, 2013). Günay (2018) also emphasizes that lecturers do not adequately fulfill their advisory duties because of their administrative tasks or irresponsibility, and even that there are jury members who do not read the theses.

The best applied practice for the official correspondence and announcements in the IESs is the utilization of electronic information and information technology systems. Nowadays, with the advancement in information and communication technologies, the entire communication process within universities is conducted by means of information systems, and thanks to this system, lecturers can instantly access announcements via their e-mails or EIMS (electronic information management system). The biggest problem under this title is to announce the news/information about the institute to students. Additionally, under student title, in a way to coincide with this problem, it is observed that students do not have enough knowledge about the postgraduate regulations. Students do not follow the institute webpage regularly, they notice the announcements late, or sometimes do not.It is important that students learn about the news and notifications related to the institute in time since some of the announcements are for transactions to be carried out at certain time intervals, such as course selection, advisor approval, thesis proposal, applications for PhD qualifying, thesis defense, and etc. Advisors and students who do not follow these announcements both experience problems themselves and leave the institute in a difficult situation. Thus, it may be suggested to prefer SMS or social media channels in order to make announcements to postgraduate students.Considering the items related to the academic and administrative personnel in the institutes of educational sciences, the administrators mostly agree on that deputy directors of the institute are accessible to lecturers and the institute student affairs staff treat lecturers with respect and in a friendly manner.

It is very important that deputy directors working in the institutes of educational sciences are accessible to lecturers, especially in terms of giving support to lecturers in academic matters. Additionally, it is understood that the staff working in the institute has a positive attitude and behavior towards lecturers. Ibret (2013) underlines that the positive communication that the personnel who will work in the institutes will establish with the lecturers is important in terms of the execution of works and processes in institutes in a smooth and qualified way. The most striking issue under this title is that the number of administrative staff in the institutes is insufficient. It is understood that the institutes of educational sciences need a large number of personnel due to the academic and administrative intensities of the institutes. Karakütük et al. (2008) determine that the number of officers in many institutes is inadequate. Based on this, it is recommended to increase the numbers of personnel depending on the intensity of the units in the IESs. When the items under the physical facilities title are evaluated, it is seen that suitable working conditions are available to the administrative staff, but this is not the same for academic activities. There are not enough conditions in order to maintain academic activities in the IESs. It is important that the IESs have studying halls independent of classrooms and technical equipment in these halls is at an adequate level in order to carry out their own academic studies. As it is in the other institutes, in the IESs, an independent teaching staff and separate classrooms are not available and physical infrastructure problems exist (Buluç \& Gelişli, 2014; Humphrey \& McCarthey, 1999; Karakütük et al., 2008; Topal, Sağlam \& Akgün, 2017), and the postgraduate courses are held by the faculty members in the classrooms of the faculties (Karakütük, 2006; Karadağ \& Özdemir, 2017; Tonbul, 2017).

Karaman and Bakırcı (2010) reveal that institutes have limited allowances and face with the lack of allowance and infrastructure. Institutes are seen as the extensions of faculties rather than independent research units. Accordingly, it appears that the problems having been identified 15 years ago still remain unsolvable. Regarding the students receiving education in the IESs, the institute administrators mostly agree on the item that students interact with their advisors, but almost disagree on the item that students have information about the postgraduate regulations. However, when the averages are taken into consideration, the average of the item that the student-advisor communication is strong is found 3.60. In other words, the average of this mostly agreed item is actually not very high. In postgraduate education, more comprehensive scientific research, specialization in the field, knowledge 
creation, and academic skills are focused on, when compared to undergraduate education (Alhas, 2006; Çıkrıkçı Demirtaşlı, 2002; Toprak \& Taşğın, 2017).

In postgraduate education, there should be a much closer and continuous communication between the academic staff and student in order to gain these skills. For this, students should see that they benefit from postgraduate education. Similar to the result revealed in the advisory services provided by the lecturers, students do not know much about the postgraduate regulations. Also, in other studies, it is seen that students do not follow and read the institute news and announcements regularly (Çoruk, Çağatay \& Öztürk, 2016). In the study by Tonbul (2017), more than half of the students who continue their postgraduate education state that their advisors do not inform them enough about the laws and regulations on postgraduate education.

It is thought that the lecturers who do not know much about the regulations and also do not review the regulations cannot guide their students and are not a good example in this respect. Students' lack of knowledge about the regulations may be one of the reasons for leaving the program uncompleted (Abiddin \& İsmail, 2011). The cooperation of the IESs with the faculty, disciplines and IESs in other universities is the other item analyzed. Although it is found that the institutes are in more contact with the disciplines and faculty, the agreement on these items is not very high. However, in the institutes, all works and transactions related to students are carried out in cooperation with the disciplines. Administrators slightly agree on the item regarding the cooperation with the IESs in other universities. While IESs maintain successful academic cooperation with faculties and departments, they cannot achieve this with the other institutes. It is recommended to carry out practices to increase coordination and cooperation among IESs. Therefore, institutes should league together to constitute joint postgraduate programs, hold congress, seminar and workshops on the problems in education, and play an active role in the resolution of educational problems of the country.

In Turkey, although there is "the Deans' Council of Faculty of Education" where the faculties of education meet to discuss on the teacher training system and the problems of faculties of education, no such a structure is available for the institutes. The institute administrators think that the interest in institute programs does not decrease and the quality of students applying to the programs is not low. For the previous year, the numbers of MS and PhD students in the institutes of educational sciences are, respectively, 33.277 and 6.711. In the academic year 2020-2021, the numbers of student are 25.850 for masters and 6.577 for doctorate degree (CoHE, 2021). Although the directors of institute and programs state that the interest in the IES programs does not decrease, there appears to be a significant decrease especially in postgraduate programs. One of the reasons for this may be that all the institutes in some universities have been closed and gathered under the name of the Institute of Postgraduate Education for the last few years, and IES students have been regarded as the students of this institute. As it is in all over the world, also in our country, the importance attached to postgraduate education is increasing day by day. However, when compared to the OECD countries, only $7 \%$ of the graduated students receive postgraduate education. Due to the low number of qualified teaching staff, the excess number of students to whom lecturers provide advisory continues to be a problem. In addition to increasing the attractiveness of postgraduate education, the institutes should be managed more effectively in terms of academic and administrative processes. Especially, enabling institutes to gain a separate institutional identity without being shadowed by faculties, to have their own teaching staff and classrooms, and to be administrated at the level of deanship, not by directors, will pave the way for a more effective management in their academic and administrative process. It is extremely important that institutes established as independent units with appropriate physical infrastructure (classrooms, labs, library, conference halls, and so on) possess their own academic staff independent of faculties in order to gain an independent institutional identity and fulfill their duties. Institutes will be able to actualize the key roles expected from them only when they attain an autonomous structure, rather than becoming institutions which handle the processes of postgraduate students.

\section{Declaration of Conflicting Interests}

The authors declared no potential conflicts of interest with respect to the research, authorship, and/or publication of this article.

\section{Funding}

The authors received no financial support for the research, author-ship, and/or publication of this article.

\section{Researchers' contribution rate}

The study was conducted and reported with equal collaboration of the researchers.

\section{Ethics Committee Approval Information}

This research was conducted in accordance with all ethical rules. It has the Ethics Committee Certificate with the Decision of Gazi University Ethics Committee Dated 14.07.2020 and Numbered 07.

\section{REFERENCES}

Abiddin, N. Z. \& Ismail, A. (2011). Attrition and completion issues in postgraduate studies for student development. International Review of Social Sciences and Humanities, 1(1), 15-99.

Aitken, L., Currey, J., Marshall, A., \& Elliott, D. (2008). Discrimination of educational outcomes between differing levels of critical care programmes by selected stakeholders in Australia: A mixed method approach. Intensive and Critical Care Nursing, 24(2), 68-77. Doi: 10.1016/j.iccn.2007.09.001. 
Aktan, O. (2020). Evaluation of postgraduate education for the teachers' career development. Journal of Higher Education and Science, 10(3), 596-607.

Alabaş, R., Kamer, T. \& Polat, Ü. (2012). Master's degree education in the career development of teachers: Reasons for preference and the problems that they face throughout the process. E-International Journal of Educational Research, 3(4), 89-107.

Alhas, A. (2006). The interpretation on post-graduate education of the state employed teachers receiving postgraduate education (The Case of Ankara Province). Master's Thesis, Gazi University, Institute of Educational Sciences, Ankara.

Arabacı, i.B. \& Akıllı, C. (2013, May). Student problems in postgraduate education. VI. Symposium of National Postgraduate Education, Sakarya, 124-133.

Arı, E., Pehlivanlar, E. \& Çömek, A. (2005). Determining the opinions and expectations of postgraduate students about the education that they receive. Dokuz Eylül University, Journal of Buca Faculty of Education, 17, 231- 235.

Arıcl, H. (2001). Scholars training-postgraduate education in social sciences. Scholars Training-Postgraduate Education. TUBA Publication, Scientific Meetings Series No 7, 53-64.

Aydemir, S. \& Çam, Ş. (2015). Opinions of graduate students about postgraduate education. Turkish Journal of Education, 4(4), 4-16.

Aydın, E. \& Hayal, M.A. (2014, June). Opinions of teachers receiving postgraduate education on postgraduate education. Proceedings of 3rd Educational Research Congress in Sakarya, Sakarya.

Barnes, J. \& Shirley, I. (2007). Strangely familiar: cross-curricular and creative thinking in teacher education. Improving Schools, 10(2), $162-179$.

Baş, G. (2013). Expectations of teachers from postgraduate education: A qualitative study (The Case of Niğde Province). Journal of Higher Education, 3(2). 67-68.

Başer, N., Narlı, S. \& Günhan, B. (2005). Views of teachers regarding problems encountered in the fields of postgraduate education and solution proposals. Dokuz Eylül University, Journal of Buca Faculty of Education, 1, 129-135.

Başer, N., Narlı, S., \& Günhan, B. (2010). Views of teachers regarding problems encountered in receiving postgraduate education and solution proposals. Dokuz Eylül University, Journal of Buca Faculty of Education, 17, 129-135.

Bayar, A. \& Duran, E. (2019). The issue of quality in postgraduate education. EUROASIA Journal of International Research, 7(20), $219-240$.

Borich, G. D. (2004). Effective teaching methods. NJ: Pearson.

Buluç, B. \& Gelişli, Y. (2014). Determination of the problems of graduate students according to students' viewpoints. Procedia - Social and Behavioral Sciences, 116, 3317-3321.

Bülbül, T. (2003). Opinions of faculty members in Ankara University Faculty of Educational Sciences on the process of student selection for postgraduate education. Ankara University Journal of Faculty of Educational Sciences, 36(1), 167-174.

Büyüköztürk, Ş. \& N. Köklü (1999). Opinions of faculty members on the scientific research competency of postgraduate students in educational sciences. Education and Science, 23(112), 18-28.

Büyüköztürk, Ş. (2011). Manual of data analysis for social sciences (15th Ed.). Ankara: Pegem.

CoHE (1981). Higher Education Law numbered 2547. (RG: $06 . \quad 11 . \quad 1981-17506)$. Retrieved from https://www.mevzuat.gov.tr/MevzuatMetin/1.5.2547.pdf.

CoHE (2021). Higher education information management system. Ankara. Retrieved from https://istatistik.yok.gov.tr/.

Creswell, J. W. (2017). Educational Research: Planning, Conducting, and Evaluating Quantitative and Qualitative Research (H. Ekşi, Trans. Ed.). Istanbul: EDAM.

Cruikshank, D. R., Jenkins, D. B. \& Metcalf, K. K. (2003). The act of teaching. New York: McGraw Hill.

Çıkrıkçı Demirtaşlı, N. (2002). A survey on the use of postgraduate education entrance exam (LES) result and other criteria for entry to postgraduate education programs. Ankara University Journal of Educational Sciences, 35(1-2), 61-70.

Çoruk, A., Çağatay, Ş. M. \& Öztürk, H. (2016). Registration and attendance issues in postgraduate education. Uşak University Journal of Social Sciences, 9(1), 165-178.

Dilci, T. \& Gürol, M. (2012). The reflections of postgraduate education to living area with the perspective of academic staff (A Case in Educational Sciences), Kastamonu Journal of Education, 20(3), 1073-1090.

Ekinci, C. E. (2011). Impact of some socio-economic factors on higher education participation in Turkey. Education and Science, 36(160), 281297.

Er, H. \& Ünal, F. (2017). Evaluation of social studies pre-service teachers' opinions on postgraduate education. Kırşehir Journal of Faculty of Educational Sciences, 18(2), 687-707.

Erdem A.R. (2007). Faculty member's responsibility to train scholars and the professional ethics required by this responsibility. Journal of Academic Design, 1(2), 77-81.

Ertem, H.Y. (2020). Structure and process in postgraduate education: organizational climate and postgraduate experiences in research universities. Mersin University Journal of Faculty of Education, 16(2): 464-483.

Etzkowitz, H. (2003). The European entrepreneurial university: an alternative to the US model. Industry and Higher Education, 17(5), 325-335.

Gök M. (2015). Postgraduate education in Turkey: number of researchers, problems of research associates and solution recommendations. Journal of Higher Education and Science, 5(2), 57-64.

Gömleksiz, M. N. \& Yıldırım, F. (2013). Opinions of graduate students on postgraduate education. VI. Symposium of National Postgraduate Education, Sakarya, 68-74.

Günay, D. (2018). Postgraduate education in Turkey and a philosophical perspective on postgraduate education. Journal of University Research, 1(2), 71-88.

Hulse, B. \& Hulme, R. (2012). Engaging with research through practitioner enquiry: the perceptions of beginning teachers on a postgraduate initial teacher education programme. Educational Action Research, 20(2), 313-329.

Humphrey, R. \& McCarthey, P. (1999). Recognizing difference: providing for graduate students. Studies in Higher Education, 24(3), 371-386.

ibiş, E. (2014). Problems of postgraduate education. Journal of Higher Education, 4(3), 117-123.

ibret, B. Ü. (2013). Quality of postgraduate education in social sciences in Turkey. Symposium Proceedings, Bartın, 37-53.

IIlhan, M., Öner Sünkür, M. \& Yılmaz, F. (2012). Analysis of primary teacher candidates' attitudes towards postgraduate education (The Case of Dicle University). Mehmet Akif Ersoy University Journal of Faculty of Education, 12(23), 22-42. 
Ince, M. L. \& Korkusuz, F. (2006). Student-faculty interaction in developing postgraduate education goals: Project report of the status of one discipline at different universities and different disciplines at a university. The Scientific Technological Research Council of Turkey. TUBITAK Project No: $104 \mathrm{~K} 093$.

Inel-Ekici, D., Ekici, M. \& Can, İ. (2020). The examination of pre-service teachers' views, expectations, and awareness about postgraduate education. SDU International Journal of Educational Studies, 7(2), 212-227. Doi: 10.33710/sduijes.676425

Karadağ, N. \& Özdemir, S. (2017). The views of faculty members and PhD students on the processes of doctoral education in Turkey. Journal of Higher Education and Science, 7(2), 267-281.

Karakütük, K. (2001). Teaching staff and scientist training: Postgraduate education planning Ankara: Anı.

Karakütük, K. (2006). Turkey postgraduate education system. Karakütük, K. (Ed.), Postgraduate teaching systems in some countries. Ankara: Ankara University Publications of Faculty of Educational Sciences.

Karakütük, K., Aydın, A., Abalı, G. \& Yıldırım, S. (2008). Views of postgraduate institute administrators of the universities in Ankara on the problems of postgraduate education. Education and Science, 33(147), 42-53.

Karaman, S. \& Bakırcı, F. (2010). Postgraduate education in Turkey: problems and solution proposals. Social Sciences Research Journal, 2, 94114.

Kaya, S. (2014). Evaluation of postgraduate education in the Department of Curriculum and Instruction. International Journal of Human Sciences, $11(2), 802-826$.

Köksalan, B., ilter, İ. \& Görmez, E. (2010). A study on socio-cultural characteristics and postgraduate education willingness of the classroom teachers (The case of Fırat, Erzincan and Inönü universities classroom teaching department). Ahi Evran University Journal of Faculty of Education, 11(3), 277-299.

Kurnaz, M.A. \& Alev, N. (2009). Primary and secondary postgraduate students' ways of selecting courses and encountered problems. Journal of Turkish Science Education, 6(3), 38-52.

Mete, Y. A. (2013). Teacher training and appointment policies in South Korea, Japan, New Zealand and Finland. International Periodical for the Languages, Literature and History of Turkish or Turkic, 8(12), 859-878.

Moore, K.D. (2005). Effective instructional strategies. CA: Sage.

Nachiappan, S., Shukor, A. A. A., Veeran, V. P. \& Andi, H. K. (2012). Differences in cognitive process among primary school teacher. Current Research Journal of Social Sciences, 4(3), 256-260.

Oluk, S. \& Çolak, F. (2005). Some problems encountered by postgraduate students working as state teachers. Journal of Buca Faculty of Education, 17, 141- 144.

Orer, H. S. (2011, May). Scientific publication performance of Turkey. 26th Ankem Congress of Antibiotics and Chemotherapy, Kızılağaç/Manavgat, 134-138.

Ören, F., Yılmaz, T. \& Güçlü, M. (2012). Analysis of teacher candidates' views on postgraduate education. Journal of Education and Training Studies, 1(2), 189-201.

Özer, Y. E. (2011). Entrepreneurial university model: A proposal for Turkey. Uludağ University Journal of Faculty of Economics and Administrative Sciences, 30(2), 85-100.

Öztemel, E. (2013). Building a research and innovation culture in higher education institutions. Journal of Higher Education, 3(1), 22-29.

Rust, F. (2009). Teacher research and the problem of practice. Teachers College Record, 111(8), 1882-1893.

Sasaki, D. G. G. \& Mällinen, S. (2018). Developing student-centered assessment for a postgraduate course designed for Basic Education Teachers. Revista Ibero-Americana de Estudos em Educação, 13(1), 520-525.

Sevinç, B. (2001). Postgraduate education practices, challenges and implementations in Turkey. DEU Journal of Faculty of Education, 34(1), 2540.

Şahin, Ç., Demir, M. K. \& Arcagök, S. (2015). Prospective teachers' opinions towards postgraduate education. Journal of Theory \& Practice in Education, 11(1), 304- 320.

Şaşmaz-Ören, F. \& Karapınar, A. (2016). Teacher candidates' professional competency perceptions and attitudes towards postgraduate education and the relationship between these variables. Journal of Higher Education, 6(3), 105-116.

Şen, Z. (2012). Criticism and recommendations on the postgraduate education system in Turkey. Journal of Higher Education, 2(1), 1-9.

TEDMEM (2019). TALIS 2018 results and evaluations on Turkey. TEDMEM Analysis Series, 6. Retrieved from https://tedmem.org/yayin/talis2018-sonuclariturkiye-uzerine-degerlendirmeler.

Türker, K. (1997). Scientist training: Postgraduate education in Turkey and the World, TÜBA Scientific Meetings Series, 7, 21-34.

Tonbul, Y. (2017). Role of institutes of social sciences in enhancing the quality of postgraduate education. Journal of Higher Education and Science, $7(1), 150-162$.

Topal, M., Sağlam, H.i. \& Akgün, Ö.E. (2017, May). Problems experienced in postgraduate education through the eyes of postgraduate students and lecturers and solutions. Proceedings of 8th Symposium of International Postgraduate Education, Sakarya, 109-117.

Toprak, E. \& Taşğın, Ö. (2017). Examining the reasons for teachers not to pursue postgraduate education. International Journal of Society Researches, 7(13), 599-615.

Ünal, Ç. \& İlter, í. (2010). Primary teacher candidates' attitudes towards postgraduate education (The case of Fırat, Erzincan and Inönü universities classroom teaching department). Atatürk University Journal of Institute of Social Sciences, 14(2), 1-18.

Varol, A. \& Şeker, S. (2008, March) Ethical Violations of Academic Staff. Workshop on the Evaluation of Education in the Republic of Turkey with Contemporary Values from the Perspective of Educational Sciences, Ankara.

Yıldız, O. (2019). Conceptual framework of entrepreneurial universities. Journal of University Research, 2(1), 25-34.

Yıldız, C. \& Göl, R. (2016). Perspectives of undergraduate students about postgraduate education. The Eurasia Proceedings of Educational \& Social Sciences, 4, 499-507. 